\title{
MESTRES SERTANEJOS E OS SANTUÁRIOS DAS RAÇAS NATIVAS: BIOGRAFIAS E RECURSOS DE PODER ENTRE GRANDES PECUARISTAS DO NORDESTE'
}

\author{
MASTERS OF DROUGHTS: \\ BIOGRAPHIES AND DOMINANCE STRATEGIES AMONG \\ BREEDER ELITES OF THE BRAZILIAN NORTHEAST
}

\author{
Valdênio Freitas Meneses*
}

\section{Introdução}

Em canais de TV voltados ao agronegócio, sites de associações de criadores e revistas especializadas em pecuária de elite do Brasil é comum deparar-se com a apresentação de nomes e biografias "notáveis". Além de atores, cantores, jogadores de futebol e outros famosos que têm a pecuária como hobby, há recorrente referência a alguns criadores como "pais fundadores" ou patronos da pecuária. Fotografados nas matérias portando chapéus, bengalas e botas, tendo em geral como plano de fundo a casa sede da fazenda e os animais, eles são apresentados como netos e/ou filhos de pecuaristas - com sobrenomes que ecoam na política eleitoral -, que tiveram o mérito de fazer reconhecidas as fazendas da família por iniciativas que agregaram valor à pecuária brasileira. Exemplo disso é a importação de animais da Índia e o cruzamento e purificação de linhagens de raças zebuínas (Bos indicus) - como a Sindi, Gir, Guzerá, Kangayan e o Nelore. Os elogios ao pioneirismo desses grandes pecuaristas frequentemente acompanham uma crítica à burocracia estatal e seus obstáculos como impostos e outras limitações que "atrapalham aqueles que têm como vocação e missão tornar uma nação bem alimentada" (REVISTA D0 SINDI, 2010, p. 5). Deslocando-se do meio pecuarista do Centro-Oeste e Sudeste, centrado em exposições anuais como as de Uberaba-MG, e indo para o semiárido nordestino, a apresentação dos pecuaristas ganha adjetivos específicos: são os "mestres sertanejos", "mestres da

\footnotetext{
* Doutorando no Programa de Pós-Graduação de Ciências Sociais em Desenvolvimento, Agricultura e Sociedade - CPDA/UFRRJ (Rio de Janeiro/RJ/BR). valdeniofmeneses@gmail.com.

1. A primeira versão desse artigo foi apresentada durante o $40^{\circ}$ Encontro Anual da ANP0CS, de 24-28 de outubro de 2016, no ST 14 Espaços rurais no Brasil contemporâneo: questões teóricas e novos temas de pesquisa.
} 
caatinga" (DINHEIRO RURAL, 2011, p.1) ou nos "camelôs das secas", "bruxos do sertão", "cabras da peste" - adjetivos dado em uma reportagem da Revista 0 Berro (EUFLAVIO, 2013). Sem apoio de universidade ou governo, estes pecuaristas conseguiram ter sucesso como empresário rural no sertão nordestino provando, "na prática", que a estiagem não é obstáculo, mas algo a ser aproveitado segundo combinação de formas de criação dos animais com as especificidades naturais. Outra particularidade nesse perfil do "patrono" pecuarista nordestino é o investimento, não apenas nos bovinos, mas também nos caprinos e ovinos: experimentos genéticos, cruzamentos e até salvação da extinção de raças nativas como Canindé, Moxotó, Azul Serrana, Cariri, dentre outras, caracterizadas pelo potencial para produção de carne, leite e couro com a vegetação e o ciclo de secas da região semiárida. Ainda sobre esse trabalho, algumas reportagens colocam os "mestres sertanejos" como responsáveis diretos por fazer com que a cabra e a ovelha deixassem de ser vistas como "a pecuária dos pobres" (GLOBO RURAL, 1988, p. 56).

Apoiado nessas percepções iniciais, proponho uma análise centrada na biografia de dois pecuaristas proprietários de fazendas tidas como referência em pecuária e convivência com as secas no Brasil: o Sr. Manoel Dantas Vilar Filho "Manelito" da Fazenda Carnaúba, em Taperoá-PB, e o Sr. João Batista de Andrade "Joãozito" da Várzea dos Gatos, em Jeremoabo-BA. A partir de como são narradas as trajetórias biográficas desses personagens, é possível evidenciar alguns dos valores sociais, práticas, estilos de vida e visões de mundo que circulam em uma fração da elite pecuarista do interior do Nordeste. Também é viável refletir sobre estratégias dessa elite para tentar transformar e, ao mesmo tempo, conservar um patrimônio fundiário e simbólico. Trata-se, portanto, de reconversões sociais, perspectiva trabalhada em pesquisas entre diferentes elites sociais seguindo o legado de Pierre Bourdieu (2015, 2016) e melhor desenvolvida em trabalhos como os de Monique Saint- Martin (1992, 1995, 2011, 2012), e no Brasil por Afrânio Garcia Jr. (1988, 1989, 2007, 2011). Observar e analisar esse tipo de estratégia social incide em algumas questões: quais condições sociais tornam possíveis essas crenças em torno de "patronos" pecuaristas do Nordeste? Que recursos são mobilizados para produzir essa aura mística dos "mestres sertanejos"? Guiado nessas questões o eixo da discussão tenta-se compreender até que ponto a imagem pública desses pecuaristas "notáveis" desenha um quadro de posicionamentos políticos mais amplos de uma elite: entre uma afırmação empresarial e moderna, mas também sob valores que se firmam em uma antiguidade e distinção ao impor uma autoimagem sertaneja, regionalista e predominantemente masculina, identificada com a propriedade da terra, a pecuária e as secas. Em torno desse argumento está o trabalho político de imposição e naturalização de uma crença na vocação rural do Brasil como "celeiro do mundo", o que, na região semiárida do Nordeste, implica em uma elite que se apresenta como descendente de uma "sociedade do couro" dos criadores de gado, desde os tempos coloniais que ocuparam o sertão na "pisada do gado". Dentro das estratégias de reconversão e imposição de poder o pertencimento a essa "linhagem" justificaria autoridade e legitimidade dessa elite para impor um modelo de pecuária e convivência com as secas politicamente favorável à grande propriedade do Nordeste. 
As atividades de pesquisa que fundamentam este trabalho fazem parte de um projeto de doutorado sobre reconversões sociais de elites pecuaristas e seus investimentos na caprinocultura na região do Cariri da Paraíba, iniciado em 2014 no Programa de Pós-Graduação de Ciências Sociais em Agricultura, Desenvolvimento e Sociedade da Universidade Federal Rural do Rio de Janeiro (CPDA/UFRRJ). 0 artigo é uma tentativa de ampliar o olhar da pesquisa de doutorado para o perfil dos pecuaristas de outros estados que abrangem a área do semiárido nordestino. Nesta proposta, foram selecionadas as seguintes fontes:

- Reportagens: edições das revistas Globo Rural (1988), Cabra e Ovelha (março a maio 2016), Dinheiro Rural (2011), Paraiba Rural (2015) e publicações ligadas ao selo Agropecuária Tropical disponíveis no arquivo digital do Centro de Referência da Pecuária Brasileira - Zebu (CRPBZ) ${ }^{2}$, Paraiba Pecuária e Agropecuária Tropical (19762010) e $O$ Berro (1995-2003);

- Autobiografias e memórias dos "mestres sertanejos": o livro Joãozito Andrade: trajetória e vocação de um sertanejo (2010) e as crônicas biográficas de Manoel Dantas Vilar Filho (2001a, 2001b, 2001c, 2004) publicadas nas revistas citadas acima e no site da Fundação Joaquim Nabuco (2001-2006);

- Catálogos de leilões e exposições: Feira de Agronegócios da Paraíba (2015); Dia D Empório Fazenda Carnaúba (2013; 2015); Material publicitário da Associação Brasileira de Criadores de Zebu (ABCZ) e Associação Brasileira de Criadores de Sindi (ABCSindi).
Acompanham a análise dessas fontes dados elaborados durante trabalho de campo quando estive nas fazendas: no final de abril de 2016, marquei uma visita com os proprietários da fazenda Várzea dos Gatos, em Jeremoabo; e em maio de 2016, durante exposições e leilões de animais na fazenda Carnaúba, em Taperoá. Consegui registrar nessas idas às fazendas um conjunto de entrevistas das quais são utilizadas aqui uma com o Sr. "Manelito" Dantas Vilar, e outras duas com os atuais proprietários da Várzea dos Gatos, os Srs. Otacilio Júnior e Ricardo Andrade, herdeiros e administradores do legado do Sr. “Joãozito” Andrade, falecido em 2011.

$\mathrm{Na}$ primeira parte do texto apresento considerações teóricas e metodológicas sobre minha experiência de pesquisa nas fazendas e o aprendizado que tive de estar diante de um universo social que fala um "idioma" pecuarista. Tento também situar o leitor em um processo social recente, de transformações sociais no meio rural-urbano, que colocou a elite pecuarista do Nordeste e sua distinção social sob risco de desclassificação. 0 tópico seguinte do artigo detalha quais as linhas narrativas que são produzidas textual e imageticamente para as biografias dos "mestres sertanejos": a memória bucólica de meninos que tiveram uma infância junto aos currais e aos vaqueiros que, mesmo passando um período fora das fazendas para estudar na cidade, acabam por abdicar de suas carreiras profissionais para, enfim, cumprir um chamado a uma vocação rural e transformar a antiga fazenda dos pais e avós em referên-

2. A maior parte do acervo das revistas Agropecuária Tropical e 0 Berro podem ser visualizadas no arquivo virtual do site da ABCZ <http://www.crpbz.org.br/Revistas/ListaRevistas/6-Revista-Agropecuaria-Tropical-Memorias-do-Zebu?page=1> 
cia na pecuária. Na terceira e última parte, após detalhar as peças desse mosaico biográfico montado pelos próprios pecuaristas, faço considerações gerais sobre como e quais valores sociais, visões de mundo e quais posicionamentos políticos são legitimados no meio dos grandes pecuaristas do Nordeste e suas afinidades mais amplas com as visões de mundo da elite do agronegócio no Brasil.

\section{0 "idioma" pecuarista de uma elite e as suas narrativas biográficas}

Ao fazer pesquisa entre elites sociais é preciso refletir quais as negociações e ritos de entrada feitos pelo sociólogo ao se inserir em um grupo que se afirma como socialmente superior, fator que influencia no vínculo pesquisador-pesquisados. Reconhecendo que "os modos de fazer e escrever sobre as pesquisas são inseparáveis dos objetos de sua reflexão" (MELUCCI, 2005, p. 9) trabalhar com elites tem implicações epistemológicas específicas diante da imposição dirigida ao pesquisador, seja direta ou velada, de símbolos de poder que dão coesão e distinção a um grupo social. Essa é uma das fontes de um "mal-estar deontológico", segundo pesquisadores da alta burguesia francesa como Michel Pinçon e Monique Pinçon-Charlot (2007): por exemplo, na situação da entrevista no espaço das elites (mansões, fazendas, escritórios, castelos, clubes etc.) é comum um poder simbólico - que se exerce naturalizado - na exposição de objetos "sagrados" junto a falas ou gestos que demonstram capitais culturais e sociais mobilizados em tentativas de convencimento e controle da pesquisa.

Levando em conta esses fatores tive de lapidar certo grau de reflexividade durante a escrita desse artigo segundo condições sociais da pesquisa que, por sua vez, direcionaram algumas escolhas teóricas e metodológicas. A primeira dessas condições trata da observação e controle de impressões face a face nas interações e diálogos, gravados ou não, no trabalho de campo nas fazendas. Diante dessas interações sociais, demarca-se um "idioma” feito não apenas por nomes de raças, conceitos de zootecnia e veterinária e procedimentos de criação no meio da grande pecuária, mas por disposições corporais, formas de falar e se apresentar socialmente. Tive de apreender traços desse "linguajar" e treinar o olhar sociológico para transitar e compreender alguns traços básicos dos recursos materiais e simbólicos que agregam pessoas ao mundo dos grandes pecuaristas. Por esses aprendizados na pesquisa de campo, partilho com as observações que remetem a um trabalho clássico das ciências sociais e que abrem a tese de Natacha Leal (2014) sobre elites de bovinos e elites de criadores no circuito de Uberaba-MG. Guardadas as diferenças, ao fazer pesquisa junto a estratos sociais da pecuária de elite brasileira é quase inevitável não recordar de passagens que explicam a relação do gado com a explicação de quase todos os fatos e sentidos da vida social entre os Nuer da África Central, descrita pelo antropólogo Evans-Pritchard (1971):

Qualquer assunto que começasse, e de qualquer ângulo que o abordasse, logo estaríamos falando de vacas e bois, vitelas e novilhos, carneiros e ovelhas, bodes e cabras, bezerros e cabritos. Já mencionei que essa obsessão - pois é isso que parece para um estranho - deve-se não somente ao grande valor econômico do gado, mas também ao fato de que ele constitui o vínculo de numerosos relacionamentos sociais. (...) seu idioma 
social é um idioma bovino. (EVANS PRITCHARD, 1978, p. 27)

Com suas ressalvas comparativas ao caso dos Nuer, o "idioma" do mundo da elite pecuarista aqui analisada é inseparável da evocação saudosa de um passado centenário das fazendas do interior do Nordeste: um insistente chamado a uma glória da “civilização do couro", narrativa protagonizada por desbravadores do sertão colonial, fundadores das fazendas, que abdicaram do litoral e, espontaneamente, "na pisada do gado" adentraram os sertões do Brasil colônia. Entre a elite pecuarista do Nordeste circula a visão de que a verdadeira brasilidade ou "sertanidade" seria essa que remete às centenárias fazendas de gado, símbolos de uma sociedade de vaqueiros e fazendeiros espalhados em uma vastidão de terras e com mais liberdade que a relação senhores e escravos da zona litorânea dos engenhos de cana de açúcar. Se do ponto de vista acadêmico, podem-se considerar já superadas essas narrativas historiográficas - desmontadas desde o trabalho de historiadores como Maria Yeda Linhares (1996) e Francisco Carlos Teixeira da Silva (1997) -, do ponto de vista do recorte deste artigo, o fundamental é indagar até que ponto as elites pecuaristas, ao evocarem essas narrativas do passado em suas biografias, memórias escritas e artigos de revistas de associações de criadores expõem padrões valorativos e percepções comuns do seu lugar social: um passado rural dos descendentes de uma elite "sertaneja resistente" mas que dina- miza uma pecuária empresarial de alto investimento zootécnico e adaptada às secas. Passam por esses valores e estilos de vida, como o gosto pela música ligada à "pega de boi” e vaquejada, à proximidade política com o ethos empresarial das associações patronais do agronegócio, ao ingresso em cursos de agronomia e veterinária das gerações mais jovens. Aqui também está o apreço por conservar a arquitetura colonial da fazenda ${ }^{3}$ junto à montagem de fotografias, arquivos e museus particulares na fazenda para expor documentos e objetos, como os centenários ferros de gado da família.

Uma outra trilha teórica e metodológica desse artigo trata da leitura das fontes escritas - como livros de biografias, memórias e genealogias de grandes proprietários e suas famílias. 0 olhar sociológico sobre esse material de fontes foi feito a partir do contraponto entre dois referenciais: de Gabriele Rosenthal (2006) e Pierre Bourdieu (2006). De uma forma sucinta esses dois nomes encabeçam tradições sociológicas ${ }^{4}$, uma alemã e outra francesa e seus respectivos direcionamentos para estudos de reconstrução e análise de biografias e trajetórias de vida. Um ponto comum dessas duas abordagens está em fazer perceber o quanto os fatos aleatórios de uma trajetória de vida são organizados sob tendências gerais que classificam e selecionam o que narrar (ou silenciar) sobre as experiências vividas. Contudo, Pierre Bourdieu (2006, p. 185) ao exigir uma ruptura com o senso comum (doxa), trata a organização da vida em "um todo coerente e orientado" como ilusões

3. Para uma análise rica sobre as variações dos padrões de arquitetura colonial das antigas fazendas e ribeiras da região Nordeste ver o livro Um sertão entre tantos outros de Nathália Diniz (2015).

4. Para uma revisão sobre tradições, pesquisas e abordagens sobre o uso de relatos orais e biográficos ver Narrativas e pesquisa biográfica na sociologia brasileira de Santos, Oliveira e Susin (2014). 
biográficas. Nessa abordagem do sociólogo francês, uma reconstrução sociológica das origens e recursos sociais que condicionam recursos textuais de biografias é vista com desconfiança, pois o pesquisador corre risco constante de referendar o "senso comum" ao abordar narrativas feitas de "criação artificial de sentidos” (BOURDIEU, 2006, p. 185). Essas ressalvas de Bourdieu acabam por colocar um grau valorativo caro à análise de fontes biográficas: se, de um lado, atesta a necessária operação sociológica de uma ruptura com uma doxa que representa o vivido como linear, do outro, sugere uma leitura, ou até o descarte, dos relatos biográficos, como se neles o sociólogo tivesse de distinguir e purificar "verdades ou falsidades". Nesse sentido, a proposta de Gabriele Rosenthal (2006) fornece melhores sugestões para o trato de uma fonte biográfica: em vez de assumir uma atitude destrutiva das biografias, manuseando-as intelectualmente como um fato meramente ilusório, a autora chama atenção para relações textuais internas entre o "eu" e o "mundo", linearidades e fatores endógenos que dão credibilidade e força de verdade ao texto biográfico. Dialogando nas tradições intelectuais alemãs com a fenomenologia e a psicologia, Rosenhtal (2006) afirma que analisar uma história de uma vida requer uma atitude analítica que considere cada parte segundo significação funcional para o todo (Gestalt).Todas as tipificações (infância, adolescência, adulto, velhice etc.) podem ser fracionadas, desde que se considere seu funcionamento na holística de uma fonte biográfica, ou seja, de como ela "funciona" no todo e emite significados e tentativas de convencimento. Sob essa perspectiva, os textos biográficos ou um arquivo pessoal de objetos e fotos, não são "provas" de fatos pretéritos mas sim constructos que entrelaçam saber e poder, orientados não só para fazer visíveis lembranças mas também para marcar zonas de esquecimentos do passado (HEYMANN, 2013).

Complementando essa reflexão, há uma outra proposta de análise de biografias feita a respeito de grandes tradições: a que Norbert Elias (1995) aciona ao analisar a vida de Wolfgang Amadeus Mozart através das interdependências e processos sociais entre mudanças na individualidade - no caso da posição social de artista -, e transformações mais amplas nas relações de poder da vida social da corte vienense no fim do século XVIII. É nesse equilíbrio de forças que Elias (1995) analisa a trajetória de Mozart, através das suas correspondências com os parentes e na produção musical de um intenso gênio outsider, e de como esse material documental expressa tensões individuais no envolvimento em interdependências sociais e relações de poder que o colocavam em uma posição inferior na sociedade de corte vienense - onde a posição de artista autônomo não era possível.

A consulta a essas abordagens sociológicas sobre o constructo biográfico torna compreensíveis alguns dos recursos sociais comuns manejados textualmente em livros, crônicas e memórias de pessoas que têm origem em elites sociais: exemplo disso está no uso de expressões antecipatórias como "já nessa época” ou "desde então", para afirmar supostos "destinos" e vocações "naturais" que os interlocutores acreditam que foram apenas sendo despertados na sua trajetória de vida. Considero que esses roteiros biográficos, amortizados de conflitos sociais e feitos a posteriori dos fatos, não são feitos de forma aleatória, mas interdependentes com as tendências de transformações nas relações de poder no meio dos grandes pecuaristas do Nor- 
deste, e do Brasil. Através da construção da imagem dos "notáveis" desse meio social há uma tendência dos textos para tentar convencer o leitor para afırmação de que essas pessoas têm uma vocação, que antes de profissional é afetiva e de "vivência sertaneja", com o meio rural e a atividade da pecuária no Nordeste. Deve-se tratar teórica e metodologicamente tais afırmativas não como maniqueísmos, mas como "verdades” construídas, crenças que são impostas e plenamente aceitas pelos autores das biografias e, principalmente, pela elite pecuarista, onde tais autores estão inseridos: é para esse público, antes de mais nada, que as biografias circulam e é nesse lugar social que emanam narrativas de poder e posições de prestígio dos biografados.

Ainda nessas fontes biográficas, são perceptiveis os olhares individualizados de processos sociais recentes de transformação no meio rural nordestino que ameaçaram o prestígio da elite pecuarista. 0 reconhecimento coletivo de que é "preciso mudar para permanecer igual" ${ }^{5}$ paira sobre essa elite, que pelo menos nas últimas três décadas, sofreu uma desclassificação dos seus principais recursos distintivos, assentados em valores construídos sobre a posse da terra, a pecuária e as secas. Mais que uma crise econômica, houve fissuras na ordem social em que agregados se "sujeitavam" aos fazendeiros "patrões" dentro de prestações e compromissos regidas por códigos de conduta e hierarquia que, no geral, pouco incluíam ou não eram decisivos os termos salariais e jurídicos - se baseavam em reciprocidades desiguais de bens, compadrio, parentesco, amizade e também ameaças com uso de violência física e intimidade sexual (RIBEIRO, 2011, p. 398).

Essa lógica de relações sociais e dominação foi sendo desmontada através de vários fatores: intensificação da migração, períodos de secas, diminuição e corte de financiamento de crédito rural nos anos 1980 até o governo Collor e crises de mercado e pragas nos produtos de exportação (como o algodão da Paraíba) além de outras tendências na década de 1990-2000 que iriam potencializar um desprestígio da elite pecuarista: as desapropriações de terras de antigas fazendas para construção de assentamentos rurais (SILVA, 2012); o avanço dos direitos trabalhistas e da previdência para os trabalhadores rurais e a presença de uma rede de políticas públicas para crédito rural, programas de transferência de renda de combate à fome, entre outras melhoras no poder aquisitivo (BACELAR, 2015). Essa mudança nas desigualdades sociais e acesso a direitos dos mais pobres fez com que a dominação da elite pecuarista dos fazendeiros sofresse desmonte na sua legitimidade, processo esse que teve similaridades com o que foi percebido em pesquisas sobre a transição dos engenhos para usinas na área canavieira do Nordeste entre os anos 1970 e 1980, feitas por Ligia Sigaud (2004) e Afrânio García Jr. (1989).

Com status social "arranhado", a elite pecuarista se tornou alvo de intenso arsenal de críticas políticas e acadêmicas. Desde pelo menos inicio da década de 1980 a

5. Retirada do filme Il Gattopardo, de Luchino Visconti (1963), baseado no livro de Tomasi de Lampedusa, a frase "é preciso que tudo mude para que tudo permaneça igual" é o lema de um dos personagens da nobreza siciliana que se vê decadente diante da necessidade de fazer alianças com a ascendente burguesia na Itália unificada do final do século XIX. 
retórica de idealização dos heróis sertanejos da civilização do couro, autoimagem da elite pecuarista, é atacada por movimentos sociais, pastorais e de críticas acadêmicas mais à esquerda: nessa visão os fazendeiros pecuaristas seriam representantes, por excelência, do "atraso" das oligarquias e do latifúndio que agrava os problemas da miséria e das secas, travando possibilidades de mudanças no sertão do Nordeste (MAIA, 2014). Essa linguagem de luta contra o setor dos grandes pecuaristas pode ser resumida em uma reflexão que abre um livro da Pastoral da Terra, que acusa a elite proprietária rural do Nordeste de genocídio devido a alta mortalidade infantil durante uma seca nos anos de 1979-1984. Assim como o ferro na pele do gado, esses movimentos sociais firmam uma "marca" sobre a elite pecuarista: "0 fazendeiro [que] come gado que come capim- terra-folhas de algodão que (...) que come forças do trabalhador que é comido pelo fazendeiro (...)" (CPT - IBASE, 1986, p.50).

Diante desse cenário, supondo que grupos sociais, principalmente elites, não “desmancham no ar”, quais seriam as estratégias de uma fração dos antigos proprietários pecuaristas - a dos que não abdicaram de posse da terra e da prática da pecuária - para lidar com as transformações que tornam seu passado e recursos distintivos cada vez mais distantes e desqualificados? É essa a questão a ser debatida ao se debruçar nas narrativas dos "mestres sertanejos" que circunscrevem seus esforços biográficos no que pode chamar de estratégias de reconversões sociais da elite que fazem parte: movimentos que se vêem na iminência de mudar para não perder prestígio mas que também não podem, a custo de perder status enquanto elite, fazer uma total conversão dos bens materiais e simbólicos "sem abandono total das antigas posições nem entrega total as novas" (SAINT-MARTIN, 2012, p. 73). São estratégias de reconversões sociais, por excelência, devido a tensão de se engajar em transformações, ao mesmo tempo que tenta conservar, manter ou maximizar uma coesão, um sentimento coletivo de superioridade que dê condições mínimas de pertencimento a um grupo que acredita ser superior, ou seja, dotado de uma história social, particular e distinta (SAINT-MARTIN, 2002).

Dentro das ciências sociais no Brasil, os estudos de Afrânio Garcia Jr. (1988, 1989, 2007, 2011) foram um dos primeiros a mobilizar empiricamente o conceito de reconversões para refletir sobre a transformação de elites agrárias e seus descendentes. Garcia Jr. analisa, como caso específico, o declínio dos senhores de engenhos e das relações personalizadas de moradia e trabalho na plantantion, intensificada entre as décadas de 1970-1980 em que herdeiros das elites canavieiras internalizam códigos de trabalho pelas leis trabalhistas e monetarização: lógicas estritamente capitalistas (GARCIA JR., 1989, p. 214). Nessas reconversões, sempre há o risco de falhas: dependendo do tempo e da estratégia, alguns proprietários podem ser vistos como atados demais a "coisas do passado" em relação aos segmentos já reconvertidos com sucesso - reconversões podem ter insucessos, dependendo do trânsito temporal/espacial de gerações das famílias. Isso é visível na trajetória biográfica de intelectuais e políticos brasileiros que, mesmo produzindo "filhos notáveis", algumas elites "falharam", ao menos em nível local, em manter e reconverter as condições de reprodução social de um status. Em um trabalho sobre as reconversões sociais nas biografias de estadistas e políticos no primeiro governo Vargas, 
José Américo e Juarez Távora, Garcia Jr. (2007) analisa como descendentes de elites canavieiras e pecuaristas, respectivamente na Paraíba e Ceará, conseguiram ingressar nos ministérios e altos cargos do governo Vargas no Estado Novo: essa ascensão nacional teve custo de alianças matrimoniais e políticas junto ao fato de suas famílias sofrerem localmente declínio de status e prestígio associados à propriedade da terra, cana-de-açúcar, gado e algodão.

\section{Vidas secas, vidas pecuaristas}

Incorporo as reflexões dessa literatura sobre biografias e reconversões sociais para visualizar como a construção política e biográfica dos mestres sertanejos é traçada segundo as seguintes linhas narrativas: a) cenas de uma infância rural e sertaneja e afırmação do passado de glória da "civilização do couro" ; b) a escolha por morar na fazenda: uma "volta ao campo" dentre rupturas ou desvios de uma trajetória profissional urbana; c) a consagração de toda uma vida a uma vocação tanto "pessoal” como da região do semiárido: o trabalho dedicado a pecuária o que, no caso específico dos caprinos e ovinos, fez com que as antigas fazendas da família fossem conhe- cidas na imprensa do meio pecuarista como "santuários das raças nativas".

\subsection{Meninos sertanejos: uma infância na fa- zenda e o passado da "civilização do couro"}

Em texto publicado na revista Agropecuária Tropical (setembro de 2004), e reproduzido na seção "Xerocentelha" no site da Fundação Joaquim Nabuco - espaço virtual cedido pelo primo e pesquisador da Fundação, o engenheiro João Suassuna -, "Manelito" Dantas Vilar rememora sobre como o seu pai, Manoel Dantas Vilar, foi um dos primeiros pecuaristas do Nordeste a criar o gado Guzerá. Os animais foram trazidos de trem e "tangidos" por estrada de terra, em 1930, da fazenda Itaoca, em Cantagalo-RJ, local do rebanho selecionado pelos filhos do famoso barão João de Abreu $^{6}$, até a Fazenda Carnaúba dos Dantas Vilar e Suassuna, em Taperoá. A crônica intitulada "0 bom começo levou o guzerá” relembra a infância de Manelito ouvindo esses fatos:

(...) Esse gado chegou aqui, tangido no pé, desde a Bahia. Ainda hoje, sei da minha inquietude nesse dia, quando [meu pai] falou da chegada iminente, repetindo que Guze-

6. Segundo perfil no site da ABCZ, “João de Abreu Júnior nasceu em Portugal, na Ilha de Madeira, em 29 de maio de 1869, filho de João de Abreu e de D. Maria de Jesus Freitas. Quando tinha oito anos imigrou para o Brasil, acompanhando um tio. Era de família humilde que sempre lidara com gado e pequenas construções em geral. Como todo imigrante, começou a vida dando duro no trabalho - aprendeu o ofício de pedreiro, cantaria e alvenaria. Aos poucos, absorveu os bons ventos advindos do impulso dado pela República Velha às obras de infraestrutura nos centros urbanos. A partir de 1888 a escravidão foi abolida, onde os serviços nas fazendas passaram a ser remunerados. Em meio às dificuldades, a lavoura de café entrou em crise e o valor das propriedades rurais caiu. 0 ensejo, no entanto, tornou-se favorável àqueles que vieram para o Brasil em busca de oportunidades. João de Abreu conseguiu adquirir uma pequena fazenda onde começou a vender madeira e dedicar-se à pecuária comprando animais para abate e revendendo -os aos abatedores. Em pouco tempo, destacou-se nos negócios de compra e venda de gado nas principais capitais brasileiras". 
rá era o bom, e o melhor era o JA [João de Abreu], porque dava leite e era puro (...) Meu pai começou a criar zebus em 1934, antes de eu nascer. Vivi, desde pequeno, num curral onde leite, João de Abreu, Cantagalo, seca, Guzerá eram assuntos do dia-a-dia e meu mundo mítico de menino, povoado dessas imagens (...). (VILAR, 2004, p.12)

Outras cenas que marcaram as lembranças da infância de Manelito foram ensinamentos e frases ditas por parentes, trabalhadores, vaqueiros e os "profetas da chuva" que circulavam durante sua infância na Fazenda Carnaúba:

"Vaca Guzerá só parte, quando o bezerro novo está junto. É para defender ele. Tenha medo não!" - Cazuza Emiliano (1944), vaqueiro, protegendo- me entre a porteira e uma vaca recém parida. Eu com o caneco de asa que ganhara, para aprender a tirar leite.

Espere por aquela, essa daqui tem o leite duro e o peito grosso. Da vaca azulada é macio e cabe na sua mão; vai encher seu caneco." Cazuza Emiliano (1944)

- Oh! vacas bonitas!" - Minha mãe (1945), no terraço, vendo passar um grupo no pátio, enquanto fazia um curativo no dedão topado do meu pé...

A gente fala e elas vão. Essas outras, ficam teimando, querendo voltar para comer mais." - Seu Chico Clementino (1945), vaqueiro, apontando as Guzerás, ensinandome a tanger o gado pro curral após bebida no açude, eu ao lado, escanchado e fagueiro, num jumento em osso.

Esses chifres, que deixam o gado até mais bonito, têm que ter serventia. Se não, a Natureza tinha tirado eles." - Seu Manoel Damião, Mestre de Açude e Profeta de Chuva, de barba e cabelos bem brancos, dos mitos do meu mundo primitivo, no escritório dos sábados, na cidade, onde eu ia escutar a administração e as conversas.

Quando vem o leite da Carnaúba, o queijo cresce..." - Maria Cajarana, queijeira sertaneja, despejando a coalhada já cozida em leite, na urupema grande da panela de barro. A gente esperando escorrer para mordiscar pedaços, no "quarto do queijo", da casa da rua.” (VILAR, 2004, p. 13)

Já o pecuarista Joãozito Andrade narra sua vida como privilegiada por ter nascido no "sertão de cima", na caatinga baiana às margens do "lendário rio Vasa-Barris", em junho de 1920 (ANDRADE, 2010, p. IV). Essa origem e o nome do rio evocam a infância ouvindo as conversas dos pais, avós e tios sobre política local, pecuária e a Guerra de Canudos, que teve batalhas que ocorreram próximas as fazendas da família. E no capítulo "Das origens a afırmação como pecuarista" Joãozito - o oitavo de nove filhos - descreve a vida na Fazenda Sitio Novo onde moravam os pais, o fazendeiro Manoel Vieira de Andrade casado com Maria Josefina de Carvalho, filha do coronel Antônio Lourenço Carvalho de Jeremoabo. Os primeiros anos de vida de Joãozito são descritos da seguinte forma:

Cresci cultivando o interesse de ir ao curral diariamente, ao cantar do galo aspirando o perfume silvestre da flor de quixabeira (...) e ouvindo o cantar das aves ao alvorecer. Presenciava o manejo do gado, a ordenha e conversava com Seu Manoel Dias, vaqueiro famoso, companhia agradável e grande amigo (...) Daí então quando chegava em casa tratava de projetar a minha fazenda de brinquedo (...) utilizava a minha própria imaginação: 
gado de icó branco e vaqueiro de caixa de abelha (...). (ANDRADE, 2010, p. 26)

Outra memória de infância relatada por Joãozito é a do pai negociando gado com outros grandes produtores da Bahia:

A noite na varanda da casa, sob a luz do luar com a cabeça no colo da minha querida mãe (...) eu ouvia atentamente as histórias que papai contava das negociações que realizava com os fazendeiros do Recôncavo [Baiano]. Falava sobre o gado Zebu que eles criavam e de um touro Nelore do Dr. Dantas Bião, que chegou a pesar mais de mil quilos. Meu pai adquiriu naquela época um lote de descendentes desse touro (...) Assim eu vivia feliz, ouvindo aquelas lindas histórias, tirando conclusões e planejando ser um criador daquele gado branco, que tanto me encantava e impressionava pela sua beleza e vivacidade. (ANDRADE, 2010, p. 21)

Além do Nelore, uma outra raça de gado marcaria a infância de Joãozito devido a um presente dado pelo seu pai ao completar um ano de idade: "uma bezerrinha da raça curraleira, descendente do gado criado por Garcia d'Ávila" (ANDRADE, 2010, p. 17). Essa linhagem de gado, segundo João Batista Andrade (2010), remete a grande casa senhorial no Brasil colônia, aos proprietários de gigantes sesmarias e desbravadores do interior do estado da Bahia que deixaram parte do rebanho nas fazendas da família Andrade porque essas eram rota e rancharia do caminho centenário de tropeiros da região do Sertão de Cima (ANDRADE, 2010, p. 66).

A figura de um patriarca do "tempo" do Brasil colônia também é citada nas crônicas autobiográficas de Manelito Dantas e memórias escritas por membros de sua família, como o trabalho de Dantas e Dantas (2008). Nelas, é mencionado o nome de Bento da Costa Vilar, patriarca da família Vilar e tido como desbravador que em 1782 fundou fazendas no sertão dos Cariris Velhos. As antigas datas de terra de Bento Vilar incluíam os cerca de 900 hectares da Fazenda Carnaúba e 4000 hectares da Fazenda Pau Leite, da família Dantas Vilar. Dentro dessa história da família e da fazenda, Manelito coloca logo nas primeiras frases da entrevista que registrou comigo "Eu sou a oitava geração nessa fazenda aqui”. Um outro símbolo dessa "passagem" de séculos de gerações dos Dantas Vilar na Carnaúba é o ferro de gado dos Vilar. Catalogados no livro chamado Ferros do Cariri: uma heráldica sertaneja, escrito em 1974 por um dos primos de Manelito, o escritor Ariano Vilar Suassuna, o símbolo do ferro da família (ao centro) faz parte da marca da fazenda:

Figura 1 - Marca da Fazenda Carnaúba

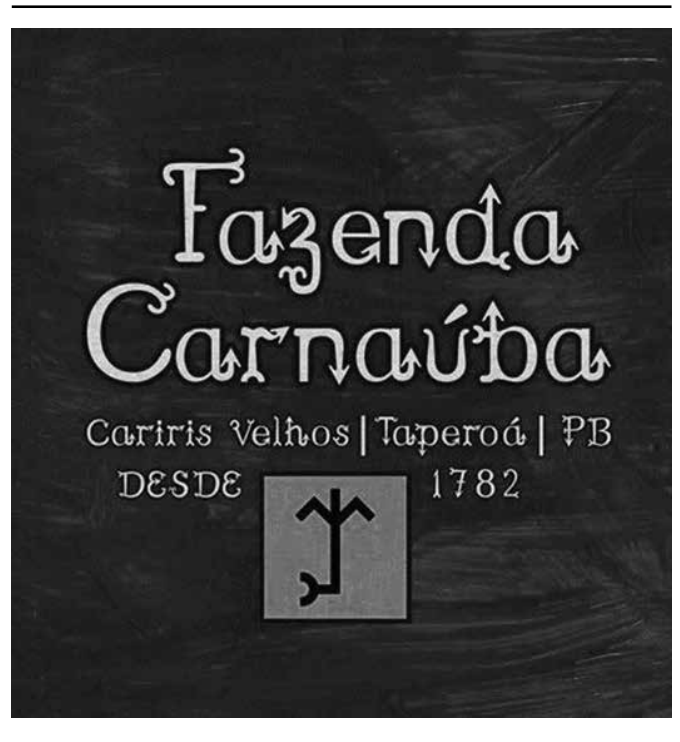

Fonte: Facebook Fazenda Carnaúba 
Em entrevista, ao falar desses símbolos da família - que também compõem a decoração da casa sede da Carnaúba -, Manelito reforça sua "luta pessoal" para recuperar o passado do sertão nordestino feito pelos homens da "sociedade do couro". Esse é o mesmo argumento da crônica "Caprinocultura no semiárido" publicadas no site da FUNDAJ (Fundação Joaquim Nabuco) e também no número 46 da revista $O$ Berro:

0 Brasil, com o Nordeste seco bem incluído, tem a vocação e o destino de ser, também, a grande nação agropecuária, sobretudo pecuária, do mundo (...) A civilização do couro foi a fase mais próspera da economia nordestina (...) Clareando o caminho (...) de viver em sintonia com a natureza desse mundo áspero, bonito, possível e mal tratado do sertão de águas desarrumadas, a pecuária de múltipla função (...) integrada por bovinos, caprinos e ovinos bem adaptados ao ambiente, recriará a civilização do couro em novas bases e o semiárido poderá se transformar (...) num belo pedaço do Brasil (VILAR, 2001, p.1)

\section{2 "A volta ao campo": escolarização e des- vios de uma carreira profissional na cidade}

Do fim do século XIX até meados do século XX, sair da fazenda da família para ir morar e estudar em internatos, nos centros urbanos das capitais, foi quase como um "ritual de passagem" na adolescência de várias gerações de jovens filhos de grandes pecuaristas da região Nordeste. No caso de Joãozito Andrade, esse ritual foi feito em aceitação de um grande desejo da mãe Maria Josefına, participante de grupos de Apostolado da Oração: a de ver um dos seus filhos tornar-se padre. Seguindo essas indicações Joãozito entrou como aluno do Seminário Santa Tereza em Salvador-BA.
Dessa época, ele registra a lembrança da saudade do gado e das plantas do sertão e as angústias vindas das dúvidas sobre sua vocação religiosa. São essas as cenas descritas ao reconstruir a memória dessa mudança das fazendas Trindade e Várzea dos Gatos para um internato religioso:

Fui indicado para conduzir a cruz durante procissão no Largo da Sé. Mas, quando olhei pra trás e vi o cortejo lembrei-me da seca no sertão. Lembrei-me da cena de quando o vaqueiro e eu passávamos, e o gado nos acompanhava em fila para comer o mandacaru assado (...) Na verdade eu estava continuamente vivendo o sertão, a minha família e o Nelore (...) (ANDRADE, 2010, p. 31)

Foi a partir de "revelações" religiosas que Joãozito explica como não abdicou, mas apenas transferiu traços da vocação religiosa para a de pecuarista. Assim, como ensinou Jesus, um "Bom Pastor" de ovelhas, Joãozito percebeu que poderia servir a Deus não somente como sacerdote: "poderia ser também criando e preservando tudo aquilo que Ele criou, como o Zebu sagrado da Índia” (ANDRADE, 2010, p. 31). Dessa maneira, Joãozito narra que esperou o fim do ano letivo de 1940 para abandonar os estudos no seminário e anunciar ao pai "a volta ao campo" e que a sua "universidade" ia ser a natureza e os animais. Em 1942 iniciaria um trabalho fundamentado na consanguinidade do gado Zebu com negociações de um pequeno rebanho junto a fazendeiros de destaque no Recôncavo Baiano como Dantas Bião, Antônio Azevedo e Antônio Mendes em Itapicuru-BA. Nesse momento da vida Joãozito afırmou sentir a verdadeira presença de Deus: 
Fiz a morada na fazenda (...) escolhi a caatinga como santuário para dedicar-me a seleção natural das espécies que idealizei desde a minha infância. Ali vivia criando o gado sagrado da Índia e outros animais: os da raça Kangayan, os caprinos da raça Canindé, os ovinos e o gado leiteiro da Trindade, submetendo-os as adversidades do clima semiárido, assim como o deserto para os rabari ${ }^{7} .0 u$, igualmente, um monge, rezando e acendendo velas para louvar e compreender a natureza que deve ser preservada e adorada, porque ela representa o próprio Deus. (ANDRADE, 2010, p. 71)

No caso de Manoel Dantas Vilar Filho, é ele que explica sua trajetória de vida de morar na fazenda e "fazer o caminho de volta ao sertão" como o inverso ao pessoal da sua geração, que ele considera privilegiada pelos governos Vargas e JK, que se profissionalizou nas universidades e, em seguida, trabalhou a vida toda no meio urbano em cargos técnicos da administração pública. Manelito aprendeu a ler em aulas na fazenda e com indicações do pai, que gostava dos livros da Euclides da Cunha e que, aos dez anos de idade, foi morar em internatos pra fazer o ginásio no Colégio Américo Batista, em Recife-PE, seguido do curso de engenharia na Universidade Federal de Pernambuco, na década de 1950. Tornando-se professor de hidrologia da UFPB, Manelito também exerceu cargos na Superintendência de Desenvolvimento do Nordeste (SUDENE), antes de 1964, e encabeçou a criação da Companhia de Abastecimento e Gestão de Esgoto da Paraíba (CAGEPA). Em entrevista, ao falar sobre sua experiência na universidade, Manelito critica a falta de centros de pesquisa pra entender a pecuária e as especificidades da seca no semiárido:

Manelito - 0 semiárido do Nordeste que é 91\% do Território da região (...) ficou fora (...) a escola de Agronomia de Salvador foi em torno do Cacau (...) a do Recife em função da cana de açúcar (...) e a do Ceará foi em função da engenharia de pesca marítima (...) o semiárido nunca entrou com um tema ou inspiração (...) ai resolveram criar uma aqui na década de 30 no Brejo de Areia, onde chove

Para Manelito, essa falha dos centros de pesquisa também esteve ligada, no início da década de 1970, a uma "americanização" prejudicial ao ensino superior brasileiro colocando um sistema de créditos e cadeiras, algo que foi definitivo para ele sair da vida acadêmica: uma de suas últimas atividades como professor foi a participação na comissão para avaliar os cursos de agronomia da UFPB - quando exigiu separar cursos específicos para pecuária. Segundo a memória de Manelito, essa saída do meio acadêmico foi simultânea a um momento dramático, o falecimento do pai: dai foi quando tomou a decisão defınitiva na sua "volta ao sertão" para morar na Fazenda Carnaúba e se dedicar ao conhecimento e experimentação "na prática”, o que nas suas palavras, é uma postura de evitar modismos vindo de tecnocratas do "sul do Brasil" e sem intermediação de universidade. Afırmando conhecer como sertanejo a pecuária e as secas, Manelito tenta provar que pode ser viável uma produção de grande porte de bovinos, caprinos e ovinos no semiárido Nordestino.

7. Rabari é uma tribo de pastores da região de Gujarat, na Índia. 
Essa é a lição de vida tirada do momento da morte do pai: firmar uma vocação como afırma em entrevista para Revista da ABCZ (Associação Brasileira de Criadores de Zebu), e reproduzida em site da CRPBZ (Centro de Referência da Pecuária Brasileira - Zebu):

Revista $A B C Z$ : 0 senhor é engenheiro por formação. Porque decidiu se dedicar à pecuária?

Manoel Dantas Vilar: Sou engenheiro civil por formação acadêmica. Por natureza e sentimento fui criador. A dedicação exclusiva a pecuária ocorreu por sucessão súbita de meu pai, há 36 anos. Foi um encargo, mas, também um reencontro com minhas raízes e minha vocação essencial (CRPBZ, 2016, p.1)

\subsection{Santuários das raças nativas: as fa- zendas modelo da pecuária caprinovina no Nordeste}

A fazenda Várzea dos Gatos (3500ha), em Jeremoabo, foi matéria de capa da revista Globo Rural de janeiro de 1988, com uma fotografia de uma cabra da raça Canindé com a frase “cabra macho, sim senhor!":

Figura 2 - Capa da revista Globo Rural (jan./1988)

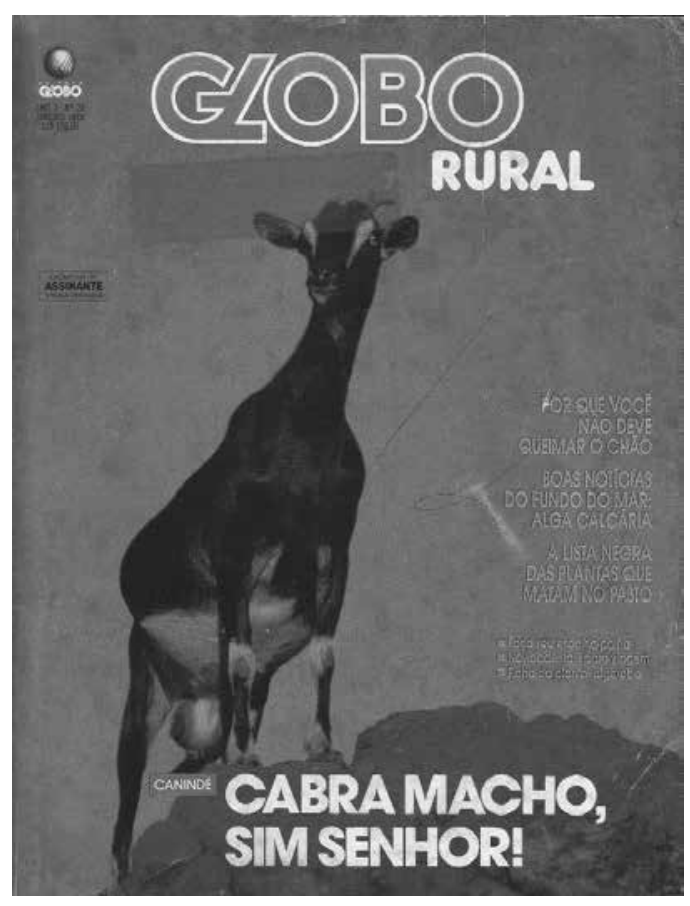

A matéria de seis páginas traz um perfil de Joãozito - um mestre sertanejo da caatinga que desistiu de estudar para padre e até de casar por gostar de ser "catingueiro mesmo (...) viver no meio do gado" (GLOBO RURAL, 1988, p. 53). Em seguida, a re- portagem fala do sucesso, desde 1942, das fazendas Trindade e Várzea dos Gatos com o gado Nelore e a recuperação das cabras da raça Canindé - fruto de uma adaptação de séculos ao clima e de cruzamentos das cabras alpinas trazidas pelos portugueses 
para o Nordeste, mas que estavam em vias de extinção desde a grande seca de 1877 . A reportagem encerra descrevendo ao leitor como Joãozito foi um criador criterioso que lutou pela pecuária de forma solitária, "aprendendo" com a vida:

Ele vai em frente sem esperar nada de governo nenhum (...) Garante o pão de cada dia com seu Nelore Na verdade são três os desafios propostos. Regenerar, preservar a raça e o desafio de torna-la uma boa leiteira (...) Joãozito não vai sossegar enquanto a Canindé dê leite para "encher um açude” (GLOBO RURAL, 1988, p. 54).

A reportagem do Globo Rural não fala de um personagem mencionado por Joãozito na sua autobiografia como fundamental para o trabalho com as cabras Canindé: a de Otacílio José, o "Dodó", filho de um vaqueiro das fazendas do avô de Joãozito, Coronel Antônio Lourenço. Foi com Dodó que Joãozito narra que fez as primeiras buscas por exemplares da raça Canindé em feiras e exposições de animais nas cidades de Jeremoabo e Uauá. No livro, Joãozito homenageia Dodó exaltando a figura do vaqueiro "como um doutor diplomado pela universidade da natureza e da aula da caatinga" (ANDRADE, 2010, p. 81).

A narrativa conta que, guiado pela própria intuição e pelos conhecimentos do vaqueiro e amigo trabalhador da fazenda, Joãozito iniciou uma busca por cabritos da raça Canindé e teve seu primeiro sucesso ao encontrar em uma feira livre um animal de pele escura. Dodó conseguiu convencer o dono do bode, que estava prestes a abatê -lo, a vender o animal; no fim da negocia- ção, o bode acabou sendo vendido por um preço três vezes maior que o do mercado (ANDRADE, 2010).

Seguindo em buscas em Portugal, Espanha e França pelo ancestral da Canindé e fazendo cruzamentos na Várzea dos Gatos, Joãozito foi construindo o que ficou conhecido como maior rebanho Canindé do Brasil - atualmente em 7000 animais - valorizado pela prolificidade ${ }^{8}$ e rusticidade tendo animais vendidos para grandes criadores e empresas como Odebrecht, exportados pra regiões da África e Ásia. 0 rebanho da Várzea dos Gatos também foi inserido em pesquisas da Embrapa Caprinos (Ceará), Universidade Federal do Rio de Janeiro (UFRJ) e Universidade Federal do Ceará (UFCE). Assim, as fazendas Várzea dos Gatos e Trindade - que fica em Cícero Dantas (BA) e onde fica o rebanho bovino -, se "tornaram laboratórios naturais" (ANDRADE, 2010).

A última reportagem com Joãozito Andrade em vida foi feita da edição $\mathrm{n}^{\circ} 78$ da revista Dinheiro Rural de abril de 2011. 0 primeiro parágrafo da matéria - ilustrado com uma fotografia de Joãozito em frente ao rebanho caprino -, fala do trabalho respeitado das fazendas Trindade e Várzea dos Gatos com o gado Nelore e com as cabras Canindé:

Joãozito posou [para a foto] com a naturalidade de quem está acostumado com os flashes e com a simplicidade do sertanejo que é. Suas origens têm tudo a ver com o negócio que construiu na pecuária (...) "Eu não fiz nada, só respeitei a necessidade dos animais na natureza, que lhes ofereceu o necessário para sobreviver na caatinga”. (DINHEIRO RURAL, 2011, p.1) 
$\mathrm{Na}$ reportagem Joãozito anuncia que estava trabalhando na seleção e aperfeiçoamento para registrar uma nova raça de ovinos deslanados e adaptados à seca, que levaria o nome de Trindade. Vindo a falecer alguns meses depois dessa matéria da Dinheiro Rural, Joãozito teve nota de homenagem compartilhada em vários sites de notícias e associações de criadores como Canal Rural ${ }^{9}$ e $\mathrm{ABCZ}^{10}$. É com orgulho que os atuais administradores da Fazenda Várzea dos Gatos e Trindade, Otacilio Júnior, filho do vaqueiro “Dodó”, e José Ricardo Andrade, sobrinho de Joãozito, afırmam assumir o compromisso de herdar e manter o legado que Joãozito deixou para pecuária brasileira

José Ricardo - eu fiquei acompanhando ali dando assistência a ele [Joãozito] e suas duas irmãs (...) enfronhado no negócio do gado dele (...) ele terminou morrendo (...) foi o último a morrer de todos (...) ele era um dos [irmãos] mais novos (...) esse [aponta pra Otacílio] nasceu com a gente (...) esse ai eu vi nascer (...) a gente se criou (...) praticamente eu mais Joãozito a gente criou ele desde pequenininho (...) e hoje a gente tá tomando conta desse legado que ele deixou pra gente (...) a parte principal seria o gado (...) pra mim e Otacílio (...) e ai a gente está administrando e dando continuidade ao trabalho (...) não com a mesma capacidade de zootecnista nato que Joãozito (...) a gente tá trabalhando com a experiência que adquiriu com ele.

Se na Bahia, a dupla Dodó e Joãozito é reconhecida no meio pecuarista pela "salvação” da raça Canindé, na Paraíba quem detém um título de raceadores de caprinos nativos é Manoel Dantas Vilar Filho e Ariano Suassuna. Após receber um prêmio pela obra $A$ Pedra do Reino, em 1971, Ariano começa, na fazenda Carnaúba - onde ficava temporadas em uma casa particular da sua família -, um projeto de criação de cabras junto com o "primo-irmão" Manelito levando em conta dois critérios: o primeiro seria melhorar a capacidade produtiva de pele, leite e carne com rusticidade e adaptação às secas - função essa de Manelito, a época criador já experiente de gado Guzerá. 0 segundo seria literário: a recuperação dos povos que formaram a identidade brasileira e sertaneja (índios, negros e brancos) através do "resgate" das raças de cabras nativas. Esse projeto pecuarista é sintonizado com a proposta armorial da literatura de Ariano Suassuna, como explica na crônica “As Cabras e o Cariri” na edição de março de 1978 da revista Agropecuária Tropical, da qual Manoel Dantas Vilar fazia parte do comitê editorial enquanto membro da Sociedade Ruralista da Paraíba. Nesse texto, o escritor faz críticas as futilidades da vida urbana e tece reflexões sobre a existência humana a partir dos caprinos: "as cabras representam para mim a porta aberta para uma atividade criadora, real e bela" (SUASSUNA, 1978, p. 35). Em seguida, Suassuna expõe alguns dos "erros e apostas" da criação do rebanho junto com Manelito:

0 primeiro erro que nos demos foi de acreditar nos números que os estudos teóricos elaborados em gabinete sobre caprinos nos ofereciam (...) montados no gabinete ou, nos melhores casos, a partir de 10 a 20 cabeças (...) houve também perdas no rebanho por doenças

9. Ver no link: <http://www.canalrural.com.br/noticias/pecuaria/pecuaria-brasileira-perde-joao-batista -andrade-13454>.

10. Ver no link: <http://www.abcz.org.br/Home/Conteudo/21408-Criador-Joaozito-Andrade-sera-sepultado-amanha-na-Bahia $>$. 
e [ataque] de cachorros (...) [Conseguimos juntar] 100 fêmeas em um rebanho que eu chamei literalmente de indubrasil vermelha e 100 da brasil indunegra, sendo todas originadas do cruzamento de reprodutores bujos e indianos com as cabras vermelhas e pretas do Cariri Paraibano ( SUASSUNA, 1978, p. 35-36).

Os experimentos zootécnicos e literários nas centenárias fazendas Carnaúba e Pau Leite começam a ser reconhecidos na década de 1990, ao mesmo tempo em que, gradativamente, artigos sobre caprinocultura aparecem com mais frequência nas edições da $A B C Z$, até que é feita uma publicação especial para essa pecuária: $O$ Berro (publicada bimestralmente de 1995 até 2013). E em uma entrevista feita para Rinaldo Santos - editor da $O$ Berro e jornalista especializado em pecuária no Nordeste - Manelito explica como ele e Ariano foram selecionando um total de 15 raças de caprinos e ovinos, montando um plantel de 2500 animais na Pau Leite -, inclusive com o registro junto à Associação Brasileira de Criadores de Caprinos de uma raça exclusiva, a Parda Sertaneja, nomeada assim por Ariano Suassuna. Em entrevista para o jornalista José Euflávio Horácio na revista O Berro, Manelito reitera as vantagens do manejo racional da criação de caprinos em contraposição à agricultura do que chama de “culturas lotéricas e técnicas de irrigação:

É desses animais [caprinos] que o povo do interior do Nordeste precisa para viver na região da seca e não o cultivo da terra para plantar grãos afirma Manelito, realçando o que chama de "cul- turas lotéricas". Para ele, "arar a terra significa desmontar o solo". (...) "Precisamos considerar a seca um componente intrínseco do trabalho rural e atuar racionalmente, reforçando a atividade mais resistente ela, como é a criação de vacas, cabras e ovelhas". (...) A solução (...) está no estímulo à criação de animais resistentes à seca e a introdução e cultivo de plantas adaptadas ao Semiárido. Afinal, é o Semiárido mais rico do mundo em leguminosas, que vem a ser a proteína da ração animal (0 BERRO, 2013).

A fazenda Carnaúba também foi tema de reportagens. Manelito ganhou o "apelido de Camelô das secas” também devido ao uso pioneiro do capim búffel australiano na década de 1980. 0 trabalho de importação e plantio dessa espécie vegetal e as técnicas de alimentação e manejo da pecuária caprina podem ser vistos em reportagens do Globo Rural, realizada em $1983^{11}$, ano de secas, e no Programa Campo Livre, em $1990^{12}$. Um outro experimento que tornou famosas as fazendas de Manelito foi a instalação de um laticínio para produção de um refinado queijo de cabra com sabores de ervas típicas da região do Cariri da $\mathrm{Pa}-$ raíba. A embalagem do queijo é feita com desenhos que seguem o estilo armorial do teatro e da arte de Ariano Suassuna, símbolos da heráldica "sertaneja" com os ferros do gado das famílias Vilar e Suassuna.

Vivendo atualmente mais recluso ${ }^{13}$ na Carnaúba, Manelito recebe visitas de parentes, amigos e pesquisadores em ocasiões como vaquejadas, leilões e no Dia D: uma exposição de animais sediada na Carnaúba,

11. Disponivel em: <https://www.youtube.com/watch?v=K9nNpJtG014>.

12. Disponivel em: <https://www.youtube.com/watch?v=F3YwBlgod1s>.

13. As mais recentes aparição pública de Manelito fora das suas fazendas foi na palestra "Avanços tecnológicos no campo" dada em 24 de maio de 2016, em razão da abertura da XXIV Semana de Zootecnia da Universidade Federal Rural de Pernambuco (UFRPE). 
começou em 2013 e já vai pra seu quarto ano. Recentemente, em 2015, Manelito Dantas foi homenageado no documentário Carnaúba, amor, a cultura e a fazenda ${ }^{14}$. A narrativa do filme exalta a figura de Dom Manelito como alguém que fez da "fraqueza a força”, o representante da oitava geração da família Dantas Vilar na fazenda, que deixa para os filhos o vínculo com a terra e o legado da Fazenda Carnaúba como um modelo de grande pecuária e convivência com a secas que, como coloca uma frase do filme, é um "santuário de raças nativas" do semiárido nordestino.

\section{A ordem social e os recursos de poder dos grandes pecuaristas do Nordeste}

A separação feita aqui de aspectos da biografia dos mestres sertanejos é apenas de exercício analítico, dentro do que foi debatido sobre elites e reconversões sociais. Considero que as narrativas sobre a vida de Manelito Dantas e Joãozito Andrade podem ser intercruzadas num plano mais amplo de possíveis tendências, ideias-núcleo que dão coesão e sentido ao mundo social dos grandes pecuaristas do Nordeste. Cruzando os dados da reflexão sobre as biografias dos "mestres sertanejos" com trechos de editoriais, artigos e publicidades de revistas como Agropecuária Tropical e $O$ Berro, ligadas a grandes sociedades pecuaristas nordestinas, é perceptível na elite pecuarista um deslocamento, movimento de ida e volta entre duas diretrizes que indicam esquemas de percepção, recursos de poder, valores e práticas sociais:

A) Um ruralismo e o ethos da propriedade da terra: a imagem dos mestres serta- nejos é a realização em termos individuais de uma vocação coletiva e política defendida por um grupo social: a de que o Brasil e, consequentemente, o Nordeste, estariam destinados a uma vocação rural, agropecuária, de "celeiro do mundo". Nesse sentido, quando Manelito fala de sua ida a Carnaúba, diante da morte do pai no fim dos anos 1960, e Joãozito justifica interromper a missão de ser padre para substitui-la pela vocação da pecuária nas fazendas Várzea dos Gatos e Trindade, estamos diante de algo mais que "acidentes" biográficos: a lembrança dos momentos, e as explicações dadas pelos biografados que indicam como a elite pecuarista do Nordeste tem afınidades eletivas com o ruralismo dos setores patronais do agronegócio brasileiro, com suas visões de nação e de defesa política da grande propriedade. Compreendo ruralismo como construção histórica nos termos da discussão proposta por Sônia Mendonça (2005): como algo que por mais que se expresse na retórica de um "retorno" a uma vida rural, não pode ser reduzido a um mero saudosismo agrário. Trata-se de um forte discurso embutido na construção republicana e de uma modernidade brasileira do século XX: a reivindicação de modernização do campo e políticas voltadas para o setor que se pensa como fiador da imagem do Brasil que alimenta o mundo é um mesmo projeto, mesmo que apareça sob distintas modalidades - seja ela mineira, carioca, pernambucana etc. (MENDONÇA, 2005). Essa ideia de uma vocação rural é acoplada a uma defesa da grande propriedade: ponto em que está a grande ambivalência de um ethos ruralista brasileiro como coloca Regina Bruno (2010, p. 12): “o mesmo grupo

14. Disponivel em: <https://www.youtube.com/watch?v=r0D4TUEcNgQ>. 
que investe em parâmetros de modernidade, produtividade e competitividade reproduz a ideia do direito absoluto da propriedade sem limites, até mesmo com uso da violência”. Outro fator característico dessa demarcação política do agronegócio - expressa em campanhas como "Sou Agro" ou no mais recente slogan "Agro é Tech, Agro é pop”, nos intervalos da TV Globo é a ausência de alternativas históricas para além de uma vocação agrária do Brasil e uma missão de exportador de alimentos (BRUNO, 2009, p. 119). Essa imagem política transposta para o cenário da elite aqui debatida, indica o discurso que coloca só e somente só a pecuária (caprinos ${ }^{15}$ e bovinos) como salvação regional: atividades que sempre foram a redenção do povo nordestino diante das secas (AGROPECUÁRIA TROPICAL 13 ED., 1979, p. 9).

A luta pelo reconhecimento dessa vocação pecuária "natural" do Nordeste ecoa em frases e posicionamentos que vêm pelo menos desde os governos militares e que fazem uma crítica ao investimento na industrialização e urbanização feita por órgãos como a Sudene. É esse o tom de lamento de um texto com críticas ao maior recurso das políticas industriais do que agrícolas, por parte do governo João Figueiredo, em editorial da edição 18 da revista Agropecuária Tropical (1980, p. 4): “o governo faz uma política voltada para uma pseudoindustria- lização que não coloca (...) carne na mesa do nordestino”. Em seguida o editorial conclui afırmando que

é uma grande mentira exibir São Paulo como uma locomotiva carregando vagões vazios (...) [ 0 Nordeste] tem vocação legítima para pecuária e não pode continuar pagando por um modelo de desenvolvimento de shoppings centers e favelas das cidades. (p. 5)

Acompanha esse lamento da industrialização e do "consumismo" uma "culpa" atribuída aos governantes as crises do algodão -pecuária do início dos anos 1980, com a praga do "Bicudo": as secas, os impostos e leis trabalhistas "pensadas para o trabalhador urbano" que destruíram a instituição da fazenda brasileira:

A lei trabalhista rural ( CLT N 5889 de junho de 1973) é um corpo de leis cheios de defeitos, concebida para problemas urbanos. A Lei e a CLT constituem um corpo estranho em qualquer fazenda tradicional, enquanto se prestar admiravelmente pras novas empresas rurais, da mentalidade industrial, que estão tomando o lugar dos antigos fazendeiros (...) Diabolicamente planejada para expulsar do campo mão de obra para alimentar as necessidades do pessoal da grande indústria. Essa lei consegue ser altamente prejudicial tanto para empregado como para em-

15. Os caprinos foram objeto de uma batalha interna no campo dos pecuaristas, expressa nos editoriais, crônicas e reportagens da Agropecuária Tropical entre os anos 1980-1990. 0 campo de disputas se dividiu entre um grupo de criadores que não defendia os caprinos e ovinos, afırmando que eles são "uma maldição" e que aceleram a desertificação - a exemplo do pernambucano José Nivaldo (1980) em artigo da Agropecuária Tropical de janeiro de 1980 -, e outra ala "ferrenha" defensora da criação de caprinos e ovinos, apoiados em artistas e intelectuais - como Ariano Suassuna na Paraíba, e Elomar Figueira de Mello na Bahia -, e pecuaristas com o perfil similar ao de Manuel Dantas Vilar e Joãozito Andrade. As movimentações do "tabuleiro" desse jogo de disputas podem ser vista na forma como os caprinos e ovinos vão ganhando espaço em publicidade de leilões, crônicas e reportagens de edições da Agropecuária Tropical até a criação de uma publicação especializada, como a revista $O$ Berro no final da década de 1980. 
pregador, dando origem ao mais cruel êxodo rural de todos os tempos (...) 0 "modelo brasileiro" quer enforcar um último peão nas tripas de um fazendeiro (...) Uma nova legislação rural deveria respeitar o fazendeiro como a instituição legitimamente brasileira ( AGROPECUÁRIA TROPICAL,-23 ED.. 1981, p. 8-12)

Outro ponto que indica afinidades de valores do ruralismo brasileiro, entre os pecuaristas nordestinos, são as formas de expressar rivalidades com outras elites: do governo Sarney até Collor os pecuaristas identificam os investidores financeiros e banqueiros como um setor que ganha com a inflação, oscilando um capital especulativo que não investe na terra, nos alimentos mas que mesmo assim é privilegiado pelos governos (AGROPECUÁRIA TROPICAL 61 ED. 1988, p.3-4 ). Por sua vez, a defesa violenta da grande propriedade da terra é expressa de forma mais clara em editoriais da Agropecuária Tropical entre os anos 19902010: a crítica à criação de assentamentos em antigas fazendas do semiárido, tidas como improdutivas, tem alvo no INCRA (Instituto Nacional de Colonização e Reforma Agrária) e principalmente na bandeira da reforma agrária levantada por pastorais e movimentos sociais, como o MST (Movimento dos Trabalhadores Rurais Sem Terra). Este movimento se torna pauta, sendo criticado pelo viés de "padres esquerdistas", de pastorais, e como uma reforma "ideológica guiada por arruaceiros que pouco se importam com as necessidades do homem do campo" (AGROPECUÁRIA TROPICAL, 134ed., 2003, p. 21).

Em sintese, dentro desse tom ruralista e em defesa da propriedade, a construção das elites pecuaristas de um "Outro", visto como "ameaça", pode ser feita em atritos com outras elites taxadas como "sem contato com a terra" como setores empresariais e financeiros até os que "disputam a terra e enganam os mais pobres”, no caso movimentos sociais que empunham bandeira da reforma agrária.

B) "Uma estirpe sertaneja": consideradas as afınidades eletivas com o ruralismo e a incorporação dos valores do ethos da propriedade da terra, cabe refletir também sobre o que há de específico no mundo dos pecuaristas nordestinos, que os difere do patronato do agronegócio do restante do Brasil. A partir das narrativas biográficas analisadas, fixo o olhar nas categorias que remetem ao regionalismo nordestino dinamizados no conjunto de fontes analisadas, e de como a elite as utiliza para construir uma distinção social. Nesse sentido, por mais que haja proximidades com o estilo empresarial ruralista exigido no mercado de genética, e exposições de toda elite dos pecuaristas brasileiros, o círculo social no qual Joãozito Andrade e Manelito Dantas são tidos como "autoridades" expressa um particular projeto político de nação, via imposição de um imaginário que se diz sertanejo e nordestino fortemente associado à fazenda, à pecuária e às secas. Daí, o desfecho do enredo biográfico como o cumprimento de sequências, de meninos de fazenda até senhores patriarcas do semiárido, em que até mesmo as rupturas com suas experiências urbanas são como "lições pessoais”, que culminam na consagração de uma vocação inescapável: ser pecuarista; "morar no campo"; ser "sertanejo, antes de tudo, um forte", ligado à terra e que sabe, há séculos, como é a vivência com o gado e as secas. Nas palavras de Ariano Suassuna (1993) na apresentação de um livro de memória da família esse é o sentido de pertencer a uma "estirpe sertaneja (...) uma 
civilização do couro que pulsa dentro de mim" (SUASSUNA, 1993, p.11).

Essa autoimagem dos pecuaristas implica passar por um debate que já tem considerável acúmulo entre cientistas sociais, historiadores, economistas e geógrafos no Brasil: a construção de uma identidade regional do Nordeste entre acirradas lutas sociais em torno de categorias como região, nação e sertão e as próprias definições de imagens do rural e urbano. Essas lutas são historicamente dramatizadas na relação entre o fenômeno da seca, as demandas e quadros do Estado, e elites - como a dos pecuaristas e proprietários de terra. Por isso, impressiona que este tema seja debatido em autores de abordagens tão díspares e pesquisando diferentes contextos históricos. Esse debate aparece: na análise da criação da Sudene; na visão marxista de Francisco Oliveira (1977); no clientelismo dentro dos quadros de políticas do Departamento $\mathrm{Na}$ cional de Obras Contra as Secas (DNOCS) de Marcel Burstyn (1985); na relação literatura e regionalismo por Rosa Godoy (1983); nas retóricas e debates entre parlamentares vista por Iná Castro (1992); e, finalmente, nos discursos de saber e poder que cristalizam, no início do século XX, uma região chamada Nordeste, no imaginário nacional, segundo Durval Albuquerque Jr. (2011).

Dentro dos limites deste artigo, é importante acionar essa discussão do elo entre elite proprietária rural/imaginário sertanejo e nordestino, e o fenômeno das secas enquanto um fator de distinção social. 0 investimento na pecuária - e nesse sentido muito mais os caprinos que bovinos -, não é apenas um negócio que visa lucro mas uma tentativa de prestígio associada à ideia de pertencer a um "sertão genuíno", valores esses que são armas de concorrência na luta interna, inclusive com o patronato e empresariado rural de outras regiões do Brasil - esses com melhores e maiores competências econômicas do que os pecuaristas nordestinos. Diferente do empresariado que detém grandes extensões de terra do Cerrado ou Centro-Oeste, as fazendas dos pecuaristas nordestinos são investidas de uma aura nostálgica e memorial combinadas com parâmetros de gestão empresarial, modernização zootécnica e de adaptação às secas. Assim, pode-se afirmar que como no caso do mundo rural reconstruído na literatura regionalista do século XX, feita por escritores que foram "meninos" de engenho, as biografias dos mestres sertanejos na fazenda pecuarista se tornam uma reconstituição de um mundo de outrora, uma particularidade que ascende à ideia geral de nação brasileira (GARCIA JR., 2011, p. 42).

Ao cruzar informações diversas, como a história de raças de caprinos, publicidade de exposições e leilões à memória de famílias proprietárias de grandes fazendas, a contribuição tentada neste artigo é de tornar visível quais estratégias de manutenção e transformação dos recursos socialmente distintos marcam essa elite rural, que se proclama representante do que seria a mais profunda brasilidade sertaneja ${ }^{16}$ : um "autêntico Nordeste" de valores sociais feitos em torno de uma "saudade", da exal-

16. Essa combinação entre tradição/passado/ideia de missão sertaneja junto à modernização técnica das fazendas se aproxima do que algumas pesquisas recentes chamam de "agronegócio sertanejo" (MAIA; CUNHA, 2017), para tentar explicar as dinâmicas de modernização de grandes propriedades rurais na região do sertão paraibano. 
tação de um bucólico passado centenário na grande propriedade da terra, e de uma rusticidade - palavra chave no vocabulário dos criadores em defesa de um projeto político, via pecuária competitiva no mercado. Nesse sentido, há o "eterno" retorno das elites políticas nordestinas ao tema das secas - algo que sempre traz nuvens carregadas de polêmicas, principalmente pelas estratégias de poder de grupos -, e que, a partir de um fenômeno natural, naturaliza e monopoliza uma identidade "nordestina" enraizada nos planos social, cultural, político e econômico de uma região do Brasil.

\section{Referências}

ABREU, C. Capítulos de História Colonial (1500-1800). 4. ed. Rio de Janeiro: Livraria Briguiet, [1907] 1954.

ABCZ. "Criador Joãozito Andrade será sepultado amanhã na Bahia” Disponível em <http://www.abcz.org.br/Home/Conteudo/21408-Criador-Joaozito-Andrade-serasepultado-amanha-na-Bahia> Acesso em 15 de novembro de 2017

ALBUQUERQUE JR. D. Nordestino de saia rodada e calcinha preta ou as novas faces do regionalismo e do machismo no Nordeste. In: QUEIROZ, A. (Org.) A reinvenção do Nordeste, v. 1, Sesc Ceará, 2010, p. 61-86.

ALBUQUERQUE, JR. D.M. A invenção do Nordeste e outras artes. 5 ed. São Paulo: Cortez, 2011.

ANDRADE, M. C. A terra e o homem no Nordeste: contribuição ao estudo da questão agrária no Nordeste. 8. ed. São Paulo: Cortez, 2011.

ANDRADE, J. B. Joãozito Andrade: vida e vocação de um sertanejo. Salvador: Do Autor, 2010, (Autobiografia).
BACELAR, T. Economia do semiárido: a crise como oportunidade. Revista Coletiva, n.15, p. 1-3, jan./abr. 2010.

BOURDIEU, P. A ilusão biográfica. In: FERREIRA, M. M; AMAD0, J. (Orgs.) Usos e abusos da história oral, 8 ed. Rio de Janeiro: FGV, 2006, p. 183-193.

PASSERON, J. C. Os herdeiros: os estudantes e a cultura. Florianópolis: Ed. da UFSC, 2014.

A distinção: crítica social do julgamento. 2 ed. Porto Alegre: Zouk, 2015.

BRUNO, R. Agronegócio, ruralismo e relações de poder. Rio de Janeiro: Mauad X, Seropedica: Edur, 2009.

BURSTYN, M. 0 poder dos donos. Petrópolis. Rio de Janeiro: Vozes, 1984.

CANAL RURAL "Pecuária Brasileira perde João Batista de Andrade”. Disponível em: $<$ http://www.canalrural.com.br/noticias/pecuaria/pecuaria-brasileira-perde-joao-batista -andrade-13454>. Acesso em 15 de novembro de 2017

CENTRO DE REFERENCIA DA PECUÁRIA BRASILEIRA (CRPBZ) - ARQUIVO DE REVISTAS. Disponível em: <http://www.crpbz.org. br/Revistas/ListaRevistas/6-Revista-Agropecuaria-Tropical-Memorias-do-Zebu>. Acesso em:10 jul. 2016.

CPT- CEPAC - IBASE. 0 genocídio do Nordeste (1979-1983). São Paulo: Mandacaru, 1989.

DANTAS, F. L.; DANTAS, M. L. R. Uma família na Serra do Teixeira: elenco e fatos. Recife: Líber, 2008, (Autobiografia).

DINIZ, N. Um sertão entre tantos outros. São Paulo: Versal, 2015.

DUQUÉ, G. Estrutura fundiária e pequena produção: um estudo de caso no Cariri Paraibano. Revista Raizes. Campina Grande: Ano IV, n 4-5, p.168-196, jan./dez. 1985. 
ELIAS, N. Mozart: Sociologia de um gênio. Rio de Janeiro: Jorge Zahar, 1995.

EVANS-PRITCHARD, E. E. Os Nuer. São Paulo: Perspectiva, 1978.

FAVARETO, A.; ABRAMOVAY, R.; OLIVEIRA, M.; DINIZ, J. F; SAES, B. Desenvolvimento territorial em uma região do semiárido brasileiro do Nordeste Brasileiro: para além das transferências de renda. Documento de trabalho n. 83. Programa Dinâmicas Territoriales Rurales. Santiago: Rimisp - Centro Latinoamericano para o desarollo rural, $p$. 1-29, 2011.

FURTADO, R. 0 Nordeste e a saga da Sudene (1958-1964). 1. ed. Arquivos Celso Furtado, v. 3 - Rio de Janeiro: Contraponto/Centro Internacional Celso Furtado de Política para o Desenvolvimento, 2009.

GARCIA JUNIOR, A. R. Libertos e sujeitos: sobre a transição para trabalhadores livres no Nordeste. Revista Brasileira de Ciências Sociais. São Paulo: v. 7, p. 5-41, 1988.

. O Sul a caminho do roçado: estratégias de reprodução camponesa e transformação social. São Paulo: Marco Zero, 1989.

. Os vice-reis do Norte: reconversão de elites agrárias e a Revolução de 1930 (19201964). Revista de Ciências Sociais. Fortaleza: Ed. UFC, v. 38 (02), p. 74-87, 2007.

. Meninos de engenho: tradições e dramas familiares feitos símbolos de brasilidade. Antropolítica. Niterói, n. 30, p. 21-47, 2011.

HEYMANN, L. Memórias de Elite: arquivos, instituições e projetos memoriais. Revista Pós Ciências Sociais, UFMA, v.8, n.15, jan./jun. 2011, p. 77-95.

HORÁCIO, J. E. (2013) 0 camelô das secas. Disponivel em: <http://www.revistaberro. com.br/?materias/ler,2069>. Acesso em: 15 abr. 2016.

LAMPEDUSA, T. 0 Gattopardo. Rio de Janeiro: Bestbolso, 2007.
LEAL, N. Nomes aos bois: zebus e zebuzeiros em uma pecuária brasileira de elite. 2014. 320f. Tese (Doutorado em Antropologia Social) - Universidade de São Paulo (PPGAS -USP), São Paulo, 2014.

LINHARES, M.Y. Pecuária, alimentos e sistemas agrários no Brasil (Séculos XVII e XVIII). Revista Tempo. Niterói, p. 101-131, 1996.

MAIA, K.; CUNHA, L. H. Narrativas sobre a grande propriedade pecuária do sertão nordestino: território da pecuária, do latifúndio e das oligarquias. Revista Raízes, UFCG, v. 35, n. 2, p. 84-100, jul./dez. 2015. Agronegócio sertanejo: dinâmicas de modernização da grande propriedade do sertão paraibano. 40 ENCONTRO ANUAL DA ASSOCIAÇÃO NACIONAL DE PÓS-GRADUAÇÃO EM CIÊNCIAS SOCIAIS - ANPOCS, 2017.

MENDONÇA, S. Ruralismo. In: MOTTA, M. Dicionário da terra. Rio de Janeiro: Civilização Brasileira, p. 411-412.

MELUCCI, A. Busca de qualidade, ação social e cultura: por uma sociologia reflexiva. In: MELUCCI, A. (Org.). Por uma sociologia reflexiva: pesquisa qualitativa e cultura. Petrópolis: Vozes, 2005. p. 25-42.

MENEZES, D. 0 outro Nordeste: ensaio sobre a evolução social da "civilização do couro" e suas implicações históricas nos problemas gerais. 2. ed. Rio de Janeiro: Artenova, 1970.

MENEZES, M. Da Paraíba para São Paulo, de São Paulo para a Paraíba: migração, família e reprodução da força de trabalho. 1985. Dissertação (Mestrado em Sociologia e Economia Rural) - Universidade Federal da Paraíba, Campina Grande, 1985.

MORAES, F. Os sertões: livro reportagem. Recife: CEPE, 2010.

MOREIRA, G. A nova cara do sertão: provocações sobre juventude e cultura contemporânea In: FREIRE, A. (Org.) Culturas dos sertões. Salvador: Edufba, 2014. p. 227-244. 
OLIVEIRA, F. Elegia para uma re(li)gião: Sudene, Nordeste, planejamentos e conflito de classes. 2. ed. Rio de Janeiro: Paz e Terra, 1981.

PINÇON, M.; PINÇON-CHARLOT. Sociologia da alta burguesia. Sociologias. Porto Alegre: Ano 9, n.18, p. 22-37, jul./dez. 2007.

RÊGO, W. L.; PINZANI, A. Vozes do Bolsa Família: autonomia, dinheiro e cidadania, 2 ed. São Paulo: Ed. UNESP, 2014.

RIBEIRO, E. M. Agregados e fazendas no nordeste de Minas Gerais. Estudos Sociedade e Agricultura, Rio de Janeiro, v.18, n. 2, p. 393-433, 2010.

ROSENTHAL, G. A estrutura e a gestalt das autobiografias e suas consequências metodológicas. In: FERREIRA, M.M; AMADO, J. (Orgs.) Usos e abusos da história oral. 8. ed. Rio de Janeiro: FGV, 2006, p. 193-198.

SAINT - MARTIN, M. A nobreza na França: a tradição como crença. Revista brasileira de Ciências Sociais. São Paulo, n. 20, p. 148162, 1992.

SANTOS, H.; OLIVEIRA, P.; SUSIN, P. Narrativas e pesquisa biográfica na sociologia brasileira: revisão e perspectivas. Revista Civitas. Dossiê Narrativas. Porto Alegre, v.14, n. 2, p. 359-382, maio/ago. 2014.

SIGAUD, L. Armadilhas da honra e do perdão: usos sociais do direito na mata pernambucana. Revista Mana, v. 10, n.1, p. 131-163, 2004.

SILVA, M. F. Reforma agrária de mercado ou atualização do clientelismo? 0 Programa Nacional de Crédito Fundiário e o assentamento de famílias sem terra no Cariri Ocidental Paraibano. 2012. 119f. Dissertação (Mestrado em Ciências Sociais) - Universidade Federal de Campina Grande, Campina Grande, 2012.

SILVEIRA, R. M. 0 regionalismo nordestino: existência e consciência da desigualdade regional. São Paulo: Moderna, 1984
TEIXEIRA DA SILVA, F.C. Pecuária e formação do mercado interno no Brasil Colônia. Revista Estudos Sociedade e Agricultura. Rio de Janeiro, 8, p. 119-156, abril, 1997.

SUASSUNA FILHO, J. Memórias e histórias. Recife: Do Autor, 2000.

SUASSUNA, A. Ferros do Cariri: uma heráldica sertaneja. Álbum. Recife: Guariba, 1974.

SUASSUNA, A. As cabras e o Cariri. In: REVISTA PARAÍBA TROPICAL, 6ed., março, 1978, p. 35-36

Apresentação. In: SUASSUNA, R.

Uma estirpe sertaneja: genealogia da Família Suassuna. João Pessoa: A União, 1993, p. 9-32.

REPORTAGEM GLOBO RURAL NA FAZENDA CARNAÚBA, 1983. Disponivel em <https:// www.youtube.com/watch?v=K9nNpJtG014> Acesso em junho de 2016.

REPORTAGEM CAMPO LIVRE, 1990. Disponivel em: <https://www.youtube.com/watch?$\mathrm{v}=\mathrm{F} 3$ YwBlgod1s $>$. Acesso em: 5 jun. 2016.

REPORTAGEM GLOBO RURAL Fazenda Carnaúba em 1983. Globo Rural. Disponível em: https://www.youtube.com/watch?v=K9nNpJtG014>. Acesso em 12 de julho de 2016

REVISTA PARAIBA PECUÁRIA, 1. Editorial. Ed.1. janeiro 1976, Ano I. Disponível em < http://www.zebu.org.br/Revistas/ListaRevistas/6-Revista-Agropecuaria-Tropical-Memorias-do-Zebu?page $=9>$ Acesso em 16 de novembro de 2017.

REVISTA AGROPECUÁRIA TROPICAL, 13, novembro, 1979. Disponível em < http://www. zebu.org.br/Revistas/ListaRevistas/6-Revista-Agropecuaria-Tropical-Memorias-do-Zebu?page=8> Acesso em 16 de novembro de 2017. 23, outubro 1981 Disponível em < http://www.zebu.org.br/Revistas/ListaRevistas/6-Revista-Agropecuaria-TropicalMemorias-do-Zebu?page=7 > Acesso em 16 de novembro de 2017. 
$.61, \quad$ janeiro/fevereiro 1988

Disponível em < http://www.zebu.org.br/Revistas/ListaRevistas/6-Revista-AgropecuariaTropical-Memorias-do-Zebu?page $=5>$ Acesso em 16 de novembro de 2017.

. 134, setembro de 2004 Disponível em < http://www.zebu.org.br/Revistas/ ListaRevistas/6-Revista-Agropecuaria-Tropical-Memorias-do-Zebu?page $=1>$ Acesso em 16 de novembro de 2017.

REVISTA DINHEIRO RURAL, 78. ed. São Paulo: Ed. Três, maio 2011.

REVISTA DO SINDI, 5. ed. Uberaba: Agropecuária Tropical, Revista da Associação Brasileira dos Criadores de Zebu (ABCZ), jan. 2010.

REVISTA GLOBO RURAL, 28. ed. São Paulo: Globo, jan. 1988.

REVISTA 0 BERRO, 30. ed. Uberaba: Agropecuária Tropical, nov./dez. 1998.

VILAR FILHO, M.D. 0 sertão frugal e verdadeiro - Crônica de uma convicção In: (Org.) BATISTA FILHO, M. Viabilização do semiárido nordestino. Recife: Instituto Materno Infantil de Pernambuco, IMIP Recife, IMIP, 2001a, p. 38-52.

Secas e ciclos secos - Sinopse analítica. In: (Org.) BATISTA FILHO, M. Viabilização do semiárido nordestino. Recife: Instituto Materno Infantil de Pernambuco, Recife, IMIP, 2001b, p. 52-58.

. (2003) A busca por elementos biológicos e conhecimentos apropriados. Disponível em: <http://www.fundaj.gov.br/ index.php?option=com_content\&view $=$ articlectid=646 Ettemid=717>. Acesso em: 10 jun. 2016.

. 0 bom começo levou o guzerá (2004).

Disponível em: <http://www.fundaj.gov.br/ index.php?option=com_contentEtview $=$ article\&tid=1155\%3Aguzera-arcaico-1-o-bomcomeco-levou-ao-guzera-\&tcatid=75\&Itemid=717>. Acesso em: 12 jul. 2016. 


\section{RESUMO}

0 artigo analisa em narrativas biográficas alguns dos recursos de poder e distinção de uma elite proprietária rural do Nordeste que tem investido na pecuária de caprinos. Em pesquisa junto a fazendas tidas como modelos de criatórios no semiárido - a Carnaúba, em Taperoá-PB, e a Várzea dos Gatos, em Jeremoabo-BA - dinâmicas de ressignificação de latifúndios que "sobreviveram" a uma crise das relações de moradia e trabalho em crise no fim do século XX. Uma delas passa pelos "mestres da caatinga": respeitados por gerações mais jovens das famílias proprietárias das fazendas, pela imprensa e universidades como figuras de alto grau de conhecimento - não apenas por ciência, mas "vivência como sertanejos" - com a pecuária e as secas. A representação dos pecuaristas na biografia dos "patriarcas" exibe um projeto político de imposição de uma vocação para pecuária em defesa da grande propriedade no semiárido nordestino

\section{PALAVRAS-CHAVE}

Elite pecuarista. Caprinocultura. Biografia.

\section{ABSTRACT}

The article analysis biographical narratives and political resources between landlord elites and goat breeders at the Brazilian Northeast. Researching model farms in the goat cattle at the states of Bahia and $\mathrm{Pa}$ raiba this paper try to explain strategies of the landlord elites beyond the crisis of rural working patterns at the final of twentieth century. One of this strategies pass through ideological creation of a "self made man" biographies and investment in selection of goat races for construct a elite market of this breed. The presentation of the landlord and goat- breeder as a "resistant" to the drought and rural patriarchy shows a political view in defense of the big properties and land concentration at the Brazilian Northeast

KEYWORDS

Landlord elites. Goat breed. Biography. 